\title{
Assessing the Effectiveness of Geography-based Online Learning During the Covid-19 Pandemic in Higher Education
}

\author{
Abdul Wahab Abdi ${ }^{1, *}$, Syahrul Ridha ${ }^{1,2}$, Muhammad Yunus ${ }^{3}$, Puspita Annaba Kamil ${ }^{4}$, \\ Intan Safiah ${ }^{5}$, Ahmad Nubli Gadeng ${ }^{1}$ \\ ${ }^{1}$ Department of Geography Education, Universitas Syiah Kuala, Jl. Teuku Nyak Arief, Banda \\ Aceh, 23111, Indonesia \\ ${ }^{2}$ Pusat Riset Ilmu Sosial dan Budaya (PRISB), Universitas Syiah Kuala, Jl. Teuku Nyak \\ Arief, Banda Aceh, 23111, Indonesia \\ ${ }^{3}$ Department of Pancasila and Civic Education,Universitas Syiah Kuala, Jl. Teuku Nyak \\ Arief, Banda Aceh, 23111, Indonesia \\ ${ }^{4}$ Department of Geography Education, STKIP Al-Washliyah, Jl. Al-Washliyah, Banda Aceh, \\ Indonesia \\ ${ }^{5}$ Department of Primary School Teacher Education,Universitas Syiah Kuala, Jl. Teuku Nyak \\ Arief, Banda Aceh, 23111, Indonesia
}

Received 26 July 2021/Revised 25 November 2021/Accepted 3 December 2021/ Published 20 December 2021

\begin{abstract}
The Covid-19 pandemic almost stalled the face-to-face learning method in all institutions across the globe. Consequently, for learning to continue uninterrupted, there was a need to change teaching mode to online using social media and other platforms. This research aimed to examine the effectiveness of online learning during the Covid-19 pandemic and the challenges geography students faced in implementing this type of study. The research used a descriptive qualitative approach involving questionnaires designed to determine the implementation of online learning and the challenges encountered. The questions were structured through synthesizing various components of learning. Random selection was used to select 305 participants from various higher education institutions in the Aceh Region, Indonesia. The results indicated that online learning during the Covid-19 pandemic was effectively implemented. However, some challenges were encountered, including students who could not fully participate since they could not log in to the provided learning platforms. Furthermore, students from rural areas had poor internet connectivity besides the inability to buy internet quota. There were many instances of reported power supply failures, and this hindered online learning. Overall, learning geography during the pandemic was effective, though it had a fair share of challenges. The research also identified the need to develop an online learning model, teaching material, and multimedia in supporting geography-based online learning.
\end{abstract}

Keywords: Assessing; Effectiveness; Geography-based online learning; Covid-19; Higher education

*Corresponding author.

Email address : wahababdi@unsyiah.ac.id (Abdul Wahab Abdi) 


\section{Introduction}

The Covid-19 pandemic has negatively impacted all sectors, especially education (Sandhu \& de Wolf, 2020). Recent statistics indicate a drastic increase in the spread of coronavirus, especially in Jakarta and East Java. This situation has led to the introduction of stringent measures, including restrictions of social gatherings, to reduce the transmission of the virus (Satuan Tugas, 2020). Educational institutions such as schools and higher learning centers were closed until such a time when the virus could be contained and transmission rates reduced. However, it was expected that learning could adopt new techniques, such as online learning platforms guided by parents and teachers. Implementing technology in the education sector could enable the education sector to achieve the set goals and objectives according to the curriculum (Mutton, 2020).

Globally, the pandemic has negatively affected the normal way of working since people fear contracting the virus (Talidong \& Toquero, 2020). The education sector has not been isolated either since learning in all institutions shifted from face-to-face to online using social media platforms (Baloran, 2020; Barnes et al., 2020). However, the education sector was unprepared for the transition, thereby experiencing various challenges in implementing online learning (Scull et al., 2020).

Today almost all schools across the globe have adopted the online learning system despite the challenges in its implementation (Barnes et al., 2020; Coolican et al., 2020; Nasri et al., 2020; Talidong \& Toquero, 2020). According to Morgan (2020), the new system has its advantages, such as preventing student regression in online learning compared to a school setup. However, the teachers and learners have experienced uncertain time transitions to new ways of learning (Allen et al., 2020). Moreover, online learning has not fully achieved the set objectives in some modules that require face-to-face interaction between teachers and students. Therefore, there is a need to have face-to-face learning-based sessions despite having an online platform to effectively achieve the set curriculum goals (Moorhouse, 2020; Osman, 2020).

With the current pandemic, learning remains disrupted unless strategic innovations and new ideas are implemented (Hazen, 2020; Hazen \& Alberts, 2021). The novelty of this research was to provide information related to learning geography in higher education based on the location of different students, either in villages or cities. The two locations have different geographical characteristics that affect the quality of learning (Thomas \& Bryson, 2021). Therefore, in a scenario where face-to-face learning is not implemented, online-based 
learning is needed using both the web and digital applications (Bryson \& Andres, 2020; Holloway et al., 2021).

Based on the available statistics and background information, the research sought to identify the effectiveness of learning during the Covid-19 pandemic in higher education institutions. The outcome was measured using the components of learning geography, which included the design of geography-based online learning, learning material, media used, learning procedure, and student participation. The research also aimed to identify various challenges faced by geography students in implementing online-based learning.

\section{Methods}

\subsection{Research Design}

The research adopted a descriptive qualitative design to analyze the effectiveness of learning geography using the online platform during the pandemic. The technique gave the effectiveness of the innovations in the future.

\subsection{Data Collection and Analysis}

The research used a questionnaire to determine the implementation of geographybased online learning during the Covid-19 pandemic in higher education. Questions were designed by synthesizing components in learning, such as online learning needs, learning design, learning materials, media utilized, implementation, and student participation, as illustrated in (Table 1).

A simple random technique was used in sampling as it represented the population, whereeach individual had the same opportunity to participate (Setyosari, 2013). The questions were divided into five categories; the need for online-based learning during Covid19 (items \#1 through \#8); the design of online-based learning (items \#9 through \#16); learning material and media used in online-based learning (items \#17 through \#23); implementation of online-based learning (items \#24 through \#35); and student participation in online-based learning during the Covid-19 pandemics (items \#36 through \#42). 
Table 1. Forty-two questions were designed to determine the effectiveness of the implementation of geography-based online learning

\begin{tabular}{|c|c|}
\hline \multicolumn{2}{|r|}{ Questions } \\
\hline \multicolumn{2}{|c|}{ Need for geography-based online learning } \\
\hline 1 & Is it necessary to have online learning during the Covid-19 pandemic? \\
\hline 2 & Is internet connectivity necessary for online learning? \\
\hline 3 & Is lack of internet connection a challenge in implementing online learning during the Covid-19 pandemic? \\
\hline 4 & Do all students get a free and adequate internet quota from the university during online learning? \\
\hline 5 & Was it necessary to have an effective platform (such as zoom, google meet, etc.) for online learning? \\
\hline 6 & It needs student ability, which is good in using digital technology/internet. \\
\hline 7 & It needs the location of the student, with internet accessibility for online learning. \\
\hline 8 & It needs the development of an online-based collaborative learning model through an e-learning system. \\
\hline \multicolumn{2}{|c|}{ Design of geography-based online learning } \\
\hline 9 & Learning is designed specially by using an e-learning system. \\
\hline 10 & Design and inform the learning goal. \\
\hline 11 & The design of the task and evaluation is suited to the learning goal. \\
\hline 12 & $\begin{array}{l}\text { The design of the learning goal is suited to the cognitive domain (remember, understand, application, } \\
\text { analysis, evaluation, and create). }\end{array}$ \\
\hline 13 & $\begin{array}{l}\text { The learning goal can be achieved through online learning using the existing platform such as zoom, google } \\
\text { meet, etc. }\end{array}$ \\
\hline 14 & $\begin{array}{l}\text { The steps of learning which are used to help to learn effectively, such as student participation and time } \\
\text { usage in learning }\end{array}$ \\
\hline 15 & Students easily do procedures and steps of online learning. \\
\hline 16 & Learning strategy is done collaboratively and centered on students. \\
\hline \multicolumn{2}{|r|}{ Learning materials and media used in geography learning } \\
\hline 17 & $\begin{array}{l}\text { Learning media such as pictures, videos, and animation can maximize understanding of learning materials } \\
\text { and increase knowledge. }\end{array}$ \\
\hline 18 & Audiovisual media (picture, animation, and video) is easily accessed. \\
\hline 19 & Learning materials are suited to the learning goal, which has been set. \\
\hline 20 & Learning materials are easily accessed during online learning. \\
\hline 21 & The scope of learning materials is global and deep. \\
\hline 22 & The sequence of learning materials in each session suited the learning goal. \\
\hline 23 & The truth of concept, word, and fact. \\
\hline \multicolumn{2}{|c|}{ The geography-based online learning procedure } \\
\hline 24 & Online learning activities increase understanding of the material being learned. \\
\hline 25 & Learning takes place according to the set time. \\
\hline 26 & The lecturer delivers well the learning goal and topic of discussion. \\
\hline 27 & The lecturer delivers the task to support learning goal achievement. \\
\hline 28 & Lecturers use the most suitable method in delivering learning materials. \\
\hline 29 & Form a group to discuss, do the project, and solve the problem. \\
\hline 30 & The lecturer demonstrates the material learned by using audiovisual media. \\
\hline 31 & Lecturers guide students to understand the materials and tasks so they can be finished well. \\
\hline 32 & The lecturer helps students to participate and contribute to discussion actively. \\
\hline 33 & Presentation of student work outcomes can increase knowledge and skill. \\
\hline 34 & Lecturer and student conclude and give feedback to learning which is going on. \\
\hline 35 & The lecturer gives motivation and delivers learning goals and topic of discussion for the next session. \\
\hline \multicolumn{2}{|r|}{ Student participation in geography-based online learning } \\
\hline 36 & In online learning, students can participate well with their friends and lecturer. \\
\hline 37 & Can communicate well with friends and lecturer. \\
\hline 38 & Can cooperate well among friends in doing the task. \\
\hline 39 & Good coordination among friends in doing the task. \\
\hline 40 & Share the task among friends objectively. \\
\hline 41 & Students deliver work outcomes compactly. \\
\hline 42 & Students had participated well in discussions, collaborations to do the task, and presenting the outcomes. \\
\hline
\end{tabular}

The questionnaires were analyzed based on a Likert scale where the respondents specified their level of agreement based on $(1=$ strongly disagree; $2=$ disagree; $3=$ neutral or 
don't know; 4 = agree; 5 = strongly agree) (Jo \& Bednarz, 2014). A total of 305 students from Aceh Province distributed in urban and rural areas were sampled to participate in the research since they experienced varying challenges. The questionnaires were filled through a Google Form sent via social media (WhatsApp group) for data collection from 28 May until 11 June 2021. This was meant to increase student awareness of the importance of embracing social media in learning circumstances (Halliwell, 2020). Additionally, a descriptive statistic technique was used to analyze the data, which was presented in bar charts to determine the response of geographic-based online learning.

\section{Results and Discussion}

The research results revealed two important findings of geography learning during the Covid-19 pandemic. First, it identified the effectiveness of the system, and second, the challenges the students faced in online learning. The elaboration of those two findings is explained as follows.

\subsection{The Effectiveness of Online Learning}

Research findings established that online learning during the Covid-19 pandemic in higher education was effective. This was determined from the student perception (79\%) regarding online learning. However, online learning experienced some challenges, for instance, students in rural settings lacked access to the internet, and therefore, they could not learn as programmed. The percentage was obtained from five learning components, including learning design, material, media of learning, a form of media used, the procedure of learning, and student participation in online learning.

\subsubsection{The need for geography-based online learning during the Covid-19 pandemic}

Online learning was designed to achieve the set curriculum goals even though the students did not have face-to-face interaction with their teachers. However, during implementation, learning did not attain an optimum level since some students used less effective platforms.In addition, students from rural areas had challenges regarding internet connectivity. On the contrary, students from urban areas did not have similar challenges, especially internet access. Therefore, the research identified a need to have a defined learning model for effective online learning. Table 2 shows the total score in identifying the need for online-based learning. 
Table 2. The score in identifying the need for geography-based online learning

\begin{tabular}{|c|c|c|c|}
\hline \multicolumn{2}{|r|}{ Question } & \multicolumn{2}{|c|}{ Score } \\
\hline 1 & The Covid-19 pandemic needs effective online learning. & 1306 & $10.7 \%$ \\
\hline 2 & A good internet connection is needed for online learning. & 1477 & $12.1 \%$ \\
\hline 3 & $\begin{array}{l}\text { Lack of internet connection becomes an obstacle in online learning during the } \\
\text { Covid-19 pandemic. }\end{array}$ & 1404 & $11.5 \%$ \\
\hline 4 & $\begin{array}{l}\text { Students get free and adequate internet quota from the university during online } \\
\text { learning. }\end{array}$ & 1234 & $10.1 \%$ \\
\hline 5 & $\begin{array}{l}\text { It needs an effective platform (such as zoom, google meet, etc.) for online } \\
\text { learning. }\end{array}$ & 1248 & $10.2 \%$ \\
\hline 6 & It needs student ability, which is good in using digital technology/internet. & 1314 & $10.8 \%$ \\
\hline 7 & $\begin{array}{l}\text { It needs the location of the student, which is well covered by internet access in } \\
\text { online learning. }\end{array}$ & 1353 & $11.1 \%$ \\
\hline 8 & $\begin{array}{l}\text { It needs the development of an online-based collaborative learning model through } \\
\text { an e-learning system. }\end{array}$ & 1249 & $10.2 \%$ \\
\hline & Total & 10585 & $86.76 \%$ \\
\hline
\end{tabular}

Table 2 shows that geography-based online learning was necessary during the Covid19 pandemic $(86.76 \%)$. This was in line with the higher education policy regarding universities which recommended research investigating the effectiveness of online learning during quarantine time, as shown in Figure 1.

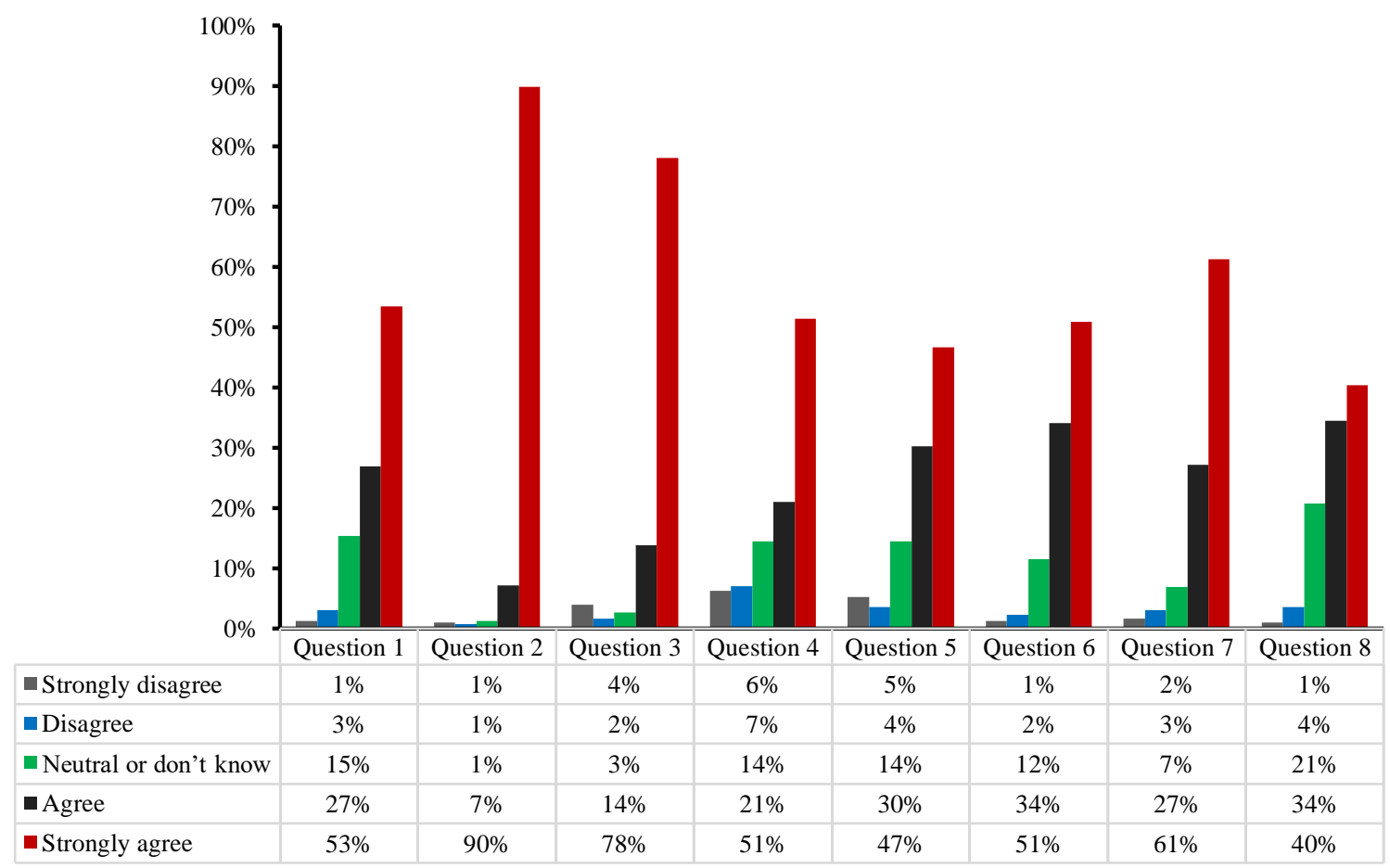

Figure 1. Percentage of student response to the need for geography-based online learning

\subsubsection{The design of geography-based online learning}

During the Covid-19 pandemic, geography-based online learning differed from the previous one, which did not engage the learners on online platforms. This section will discuss 
student responses to the learning design developed by the lecturer. Table 3 shows the total score of student response to the design of learning during the Covid-19 pandemic.

Table 3. The score of student response to the design of geography-based online learning

\begin{tabular}{|c|c|c|c|}
\hline \multirow[b]{2}{*}{9} & Question & \multicolumn{2}{|c|}{ Score } \\
\hline & Learning is designed specially by using an e-learning system. & 1140 & $9.3 \%$ \\
\hline 10 & Design and inform the learning goal. & 1288 & $10.6 \%$ \\
\hline 11 & The design of the task and evaluation is suited to the learning goal. & 1270 & $10.4 \%$ \\
\hline 12 & $\begin{array}{l}\text { The design of the learning goal is suited to the cognitive domain } \\
\text { (remember, understand, application, analysis, evaluation, and create). }\end{array}$ & 1211 & $9.9 \%$ \\
\hline 13 & $\begin{array}{l}\text { The learning goal can be achieved through online learning using the existing } \\
\text { platform such as zoom, google meet, etc. }\end{array}$ & 1146 & $9.4 \%$ \\
\hline 14 & $\begin{array}{l}\text { The steps of learning which are used to help to learn effectively such as student } \\
\text { participation and time usage in learning. }\end{array}$ & 1186 & $9.7 \%$ \\
\hline 15 & Students easily do procedures and steps of online learning. & 1067 & $8.7 \%$ \\
\hline 16 & Learning strategy is done collaboratively and centered on students. & 1152 & $9.4 \%$ \\
\hline & Total & 9460 & $77.54 \%$ \\
\hline
\end{tabular}

The research found out that geography-based online learning was implemented as planned at a response rate of (77.54\%) as shown in Table 3 . The finding established that learning plans were prepared hurriedly without an in-depth analysis of the studying environment. Additionally, it was noted that the lecturers introduced new learning materials when students were already in the mid-semester, resulting in confusion besides not covering the required content fully. Furthermore, the Indonesian policy regarding online learning was established in March 2020, whereas the lectures began in January 2020, and this led to learning sessions disruptions. In adapting to the new normal, it is necessary to continue implementing the online learning system and keep improving the hitches identified towards achieving the set goals. Figure 2 corroborates the finding of the design of learning in the form of a percentage of student response to the design of online learning, which had been developed by the lecturers.

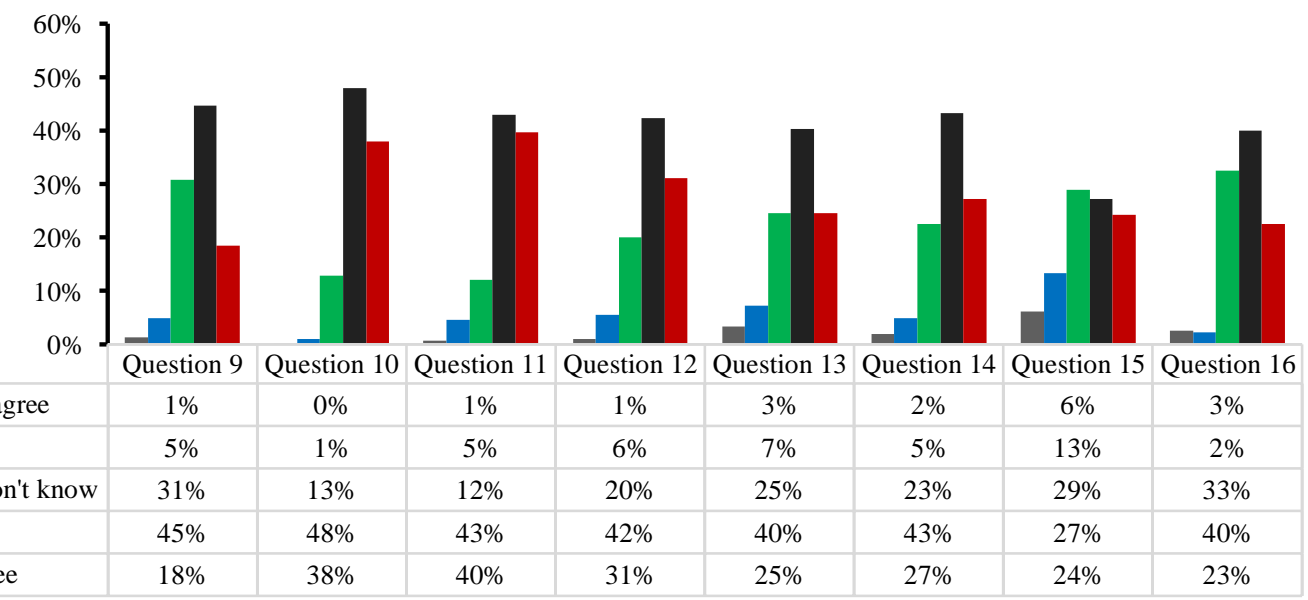

Figure 2. Student response to the design of geography-based online learning 
Universitas Syiah Kuala is among the institutions using system management learning (E-learning) before the Covid-19 pandemic, which has helped students continue with studies, as shown in (Figure 3). Thus, it is expected that online learning can be implemented in other higher learning institutions in Aceh, for both public and private institutions.

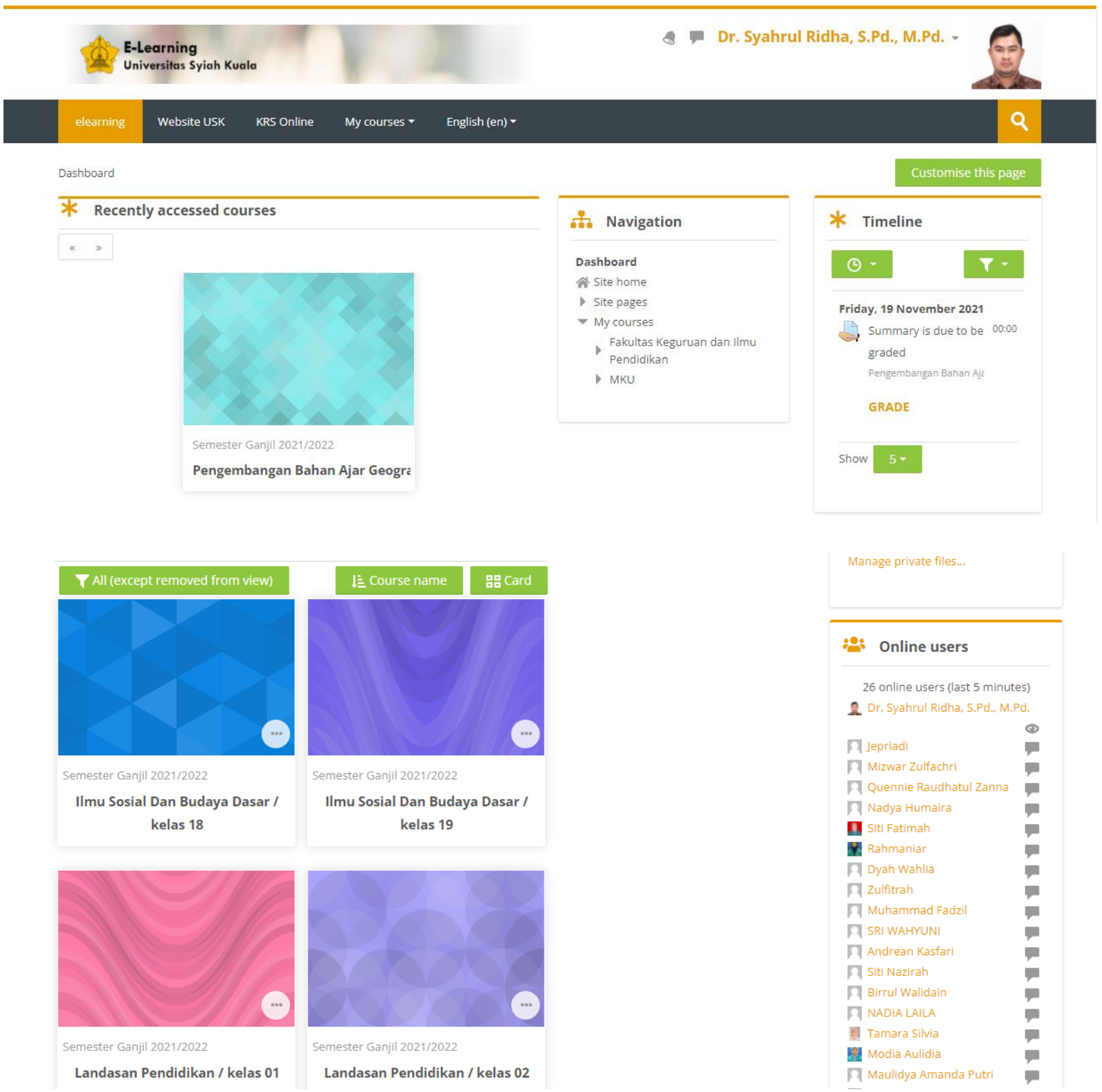

Figure 3. E-Learning platform inUniversitas Syiah Kuala

\subsubsection{Learning Materials and Media}

The current learning materials and media used in online learning do not differ from those used before the Covid-19 pandemic. The materials are suited with an online learning goal set before, whereas learning media dominantly uses audiovisual such as media display through YouTube and other learning resources. The total score of suitability between learning materials and learning media used in online learning is shown in Table 4. 
Table 4. The score of student response to learning materials and media used in geography learning

\begin{tabular}{|c|c|c|c|}
\hline \multicolumn{2}{|r|}{ Question } & \multicolumn{2}{|c|}{ Score } \\
\hline 17 & $\begin{array}{l}\text { Learning media such as pictures, video, animation can function to } \\
\text { maximize understanding of learning materials and increase knowledge. }\end{array}$ & 1323 & $12.4 \%$ \\
\hline 18 & Audiovisual media (picture, animation, and video) is easily accessed. & 1146 & $10.7 \%$ \\
\hline 19 & Learning materials are suited to the set learning goal. & 1241 & $11.6 \%$ \\
\hline 20 & Learning materials are easily accessed. & 1101 & $10.3 \%$ \\
\hline 21 & The scope of learning materials (global) and deep. & 1102 & $10.3 \%$ \\
\hline 22 & $\begin{array}{l}\text { The sequence of learning materials in each session suited the learning } \\
\text { goal. }\end{array}$ & 1198 & $11.2 \%$ \\
\hline 23 & The truth of concept, word, and fact. & 1192 & $11.2 \%$ \\
\hline & Total & 8303 & $77.78 \%$ \\
\hline
\end{tabular}

Table 4 shows materials and media used for online learning, which were deemed effective at a rate of $(77.78 \%)$. This was possible since the learning materials enhanced the achievement of the set goals according to the curriculum. However, learning media such as pictures, video, animation functions were enough to maximize the use of the five senses in understanding the learning material. Therefore, the lecturers needed to develop learning materials and media that could provide the required content. Figure 4 shows the percentage of student response to learning material and media used during the Covid-19 pandemic.

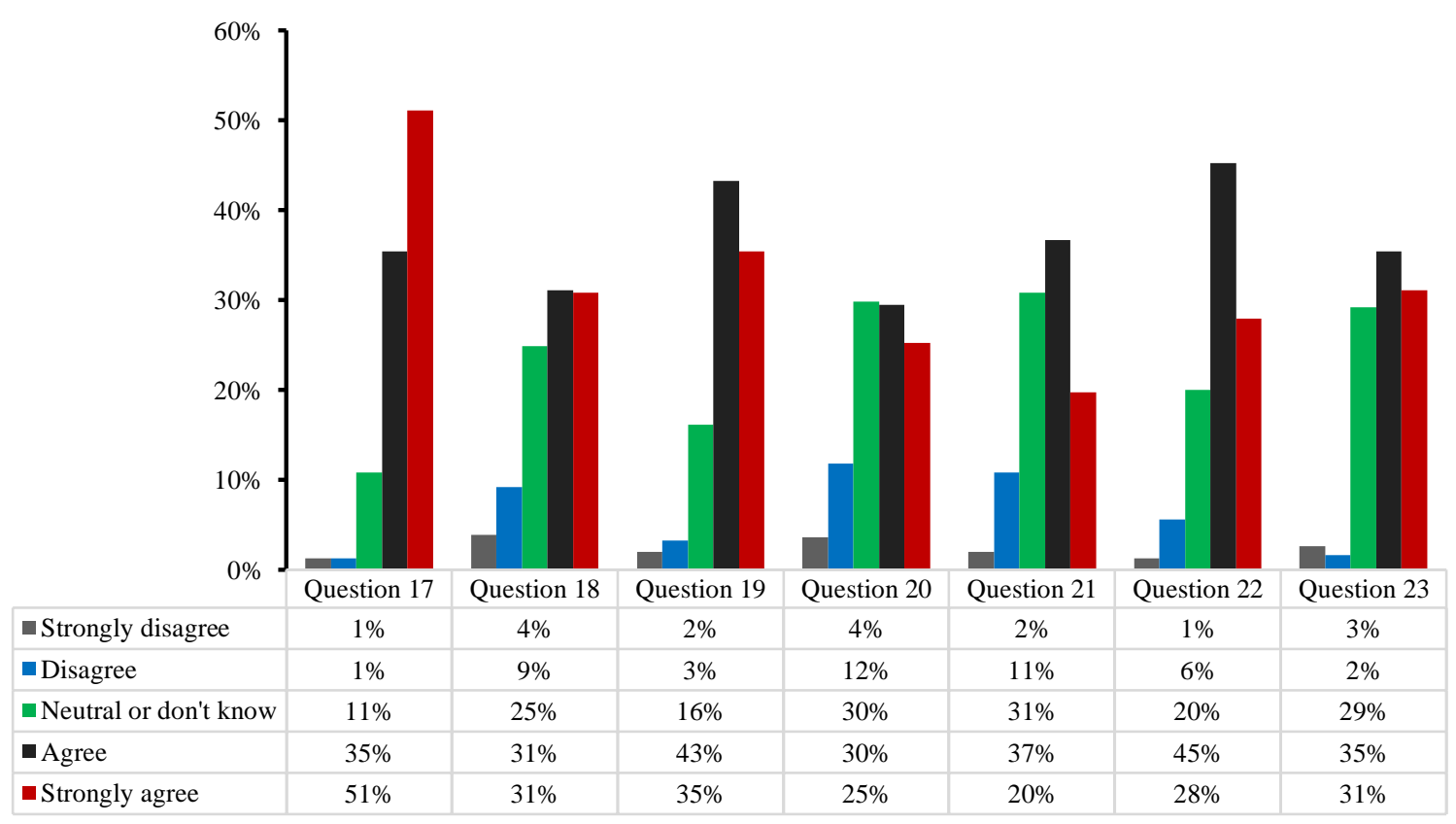

Figure 4. Student response to learning materials and media used in geography learning

\subsubsection{Learning procedure}

The procedure of online-based learning needs to be followed in accordance with the learning plan. Table 5 shows the efficacy of the procedure or learning steps. 
Table 5. The score of student response to the geography-based online learning procedure

\begin{tabular}{|c|c|c|c|}
\hline & Question & \multicolumn{2}{|c|}{ Score } \\
\hline 24 & $\begin{array}{l}\text { Online learning activities increase understanding of the material, which is being } \\
\text { learned. }\end{array}$ & 1000 & $5,5 \%$ \\
\hline 25 & Learning takes place in accord with the time, which had been determined. & 1142 & $6,2 \%$ \\
\hline 26 & The lecturer delivers well the learning goal and topic of discussion. & 1185 & $6,5 \%$ \\
\hline 27 & The lecturer delivers the task to support learning goal achievement. & 1182 & $6,5 \%$ \\
\hline 28 & Lecturers use the method, which is suitable in delivering learning materials. & 1225 & $6,7 \%$ \\
\hline 29 & Form a group to discuss, do the project, and solve the problem. & 1127 & $6,2 \%$ \\
\hline 30 & The lecturer demonstrates the material learned by using audiovisual media. & 1143 & $6,2 \%$ \\
\hline 31 & $\begin{array}{l}\text { The lecturer guide students to understand the materials and tasks so they can be } \\
\text { finished well. }\end{array}$ & 1230 & $6,7 \%$ \\
\hline 32 & $\begin{array}{l}\text { The lecturer helps students to participate and contribute to the discussion } \\
\text { actively. }\end{array}$ & 1234 & $6,7 \%$ \\
\hline 33 & Presentation of student work outcomes can increase knowledge and skill. & 1214 & $6,6 \%$ \\
\hline 34 & Lecturer and student conclude and give feedback to learning which is going on. & 1205 & $6,6 \%$ \\
\hline 35 & $\begin{array}{l}\text { The lecturer gives motivation and delivers learning goals and topic of } \\
\text { discussion for the next session. }\end{array}$ & 1268 & $6,9 \%$ \\
\hline & Total & 14155 & $77,35 \%$ \\
\hline
\end{tabular}

The research identified that the online-based procedures were recommendable for effective learning plans at a score of (77.35\%). Although some factors could not be determined in the current learning due to inadequate time, the online platform provided an understanding of the material. Students were also not familiar with online learning platforms such as Zoom and Google Meet, thus spending a lot of time connecting to the system. Figure 5 shows the percentage of student responses concerning procedure/steps of learning.

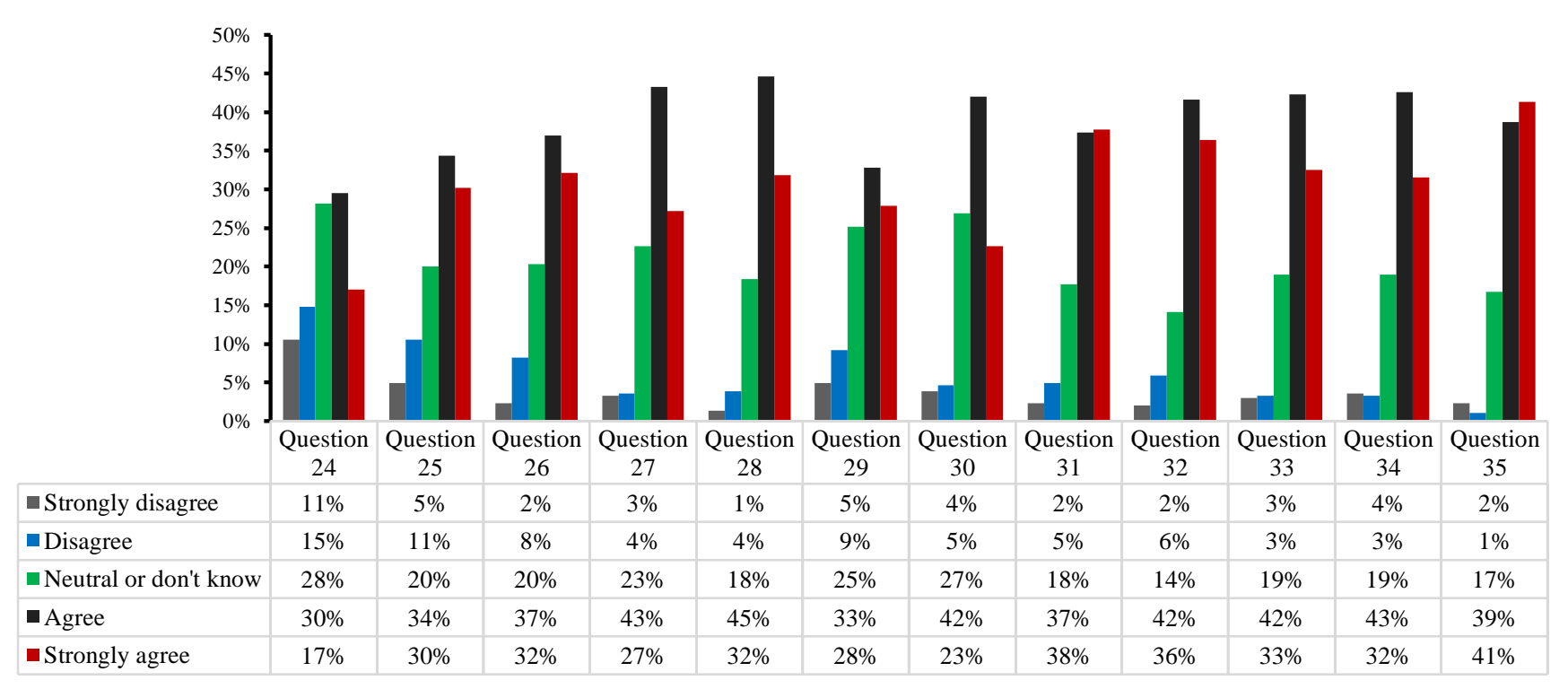

Figure 5. Student response to procedure/steps of geography-based online learning

\subsubsection{Student participation in geography learning}

The level of student participation was used to establish whether online learning was being implemented effectively during the pandemic.The assessment was determined through 
the participation of lecturers and students in solving online problems by giving theoretical and practical contributions. The students coulduse social media platforms such as WhatsApp, Instagram, and YouTube applications with minimal challenges (Halliwell, 2020; Salehudin et al., 2020). Table 6 shows the score of student participation response to online learning.

Table 6 . The score of student participation response in geography-based online learning

\begin{tabular}{|c|c|c|c|}
\hline & Question & \multicolumn{2}{|c|}{ Score } \\
\hline 36 & In online learning, students can participate well both with their friends and lecturer. & 1170 & $11.0 \%$ \\
\hline 37 & Can communicate well both with friend and lecturer. & 1180 & $11.1 \%$ \\
\hline 38 & Can cooperate well among friends in doing the task. & 1155 & $10.8 \%$ \\
\hline 39 & coordinate well among friends in doing the task. & 1181 & $11.1 \%$ \\
\hline 40 & Share the task among friends objectively. & 1189 & $11.1 \%$ \\
\hline 41 & Students deliver work outcomes compactly. & 1162 & $10.9 \%$ \\
\hline 42 & $\begin{array}{l}\text { On the whole, students had participated well in discussing, collaborating to do the } \\
\text { task, and presenting work outcomes. }\end{array}$ & 1205 & $11.3 \%$ \\
\hline & Total & 8242 & $77.21 \%$ \\
\hline
\end{tabular}

Table 6 shows that during the Covid-19 pandemic, students participated in online learning $(77.21 \%)$ despite the challenges encountered. Some of the contributing factors that hindered participation included location. The difference in the location greatly influenced the internet connectivity and other social factors making it difficult for students, especially in the rural areas, to participate fully. Besides, students living in rural areas were from low-income families, making it difficult to purchase an internet quota. Nevertheless, higher education institutions such as Universitas Syiah Kuala provided a subsidy of internet quota for online learning during the Covid-19 pandemic. Figure 6 shows the percentage of student participation in following online learning dur-ing the Covid-19 pandemic.

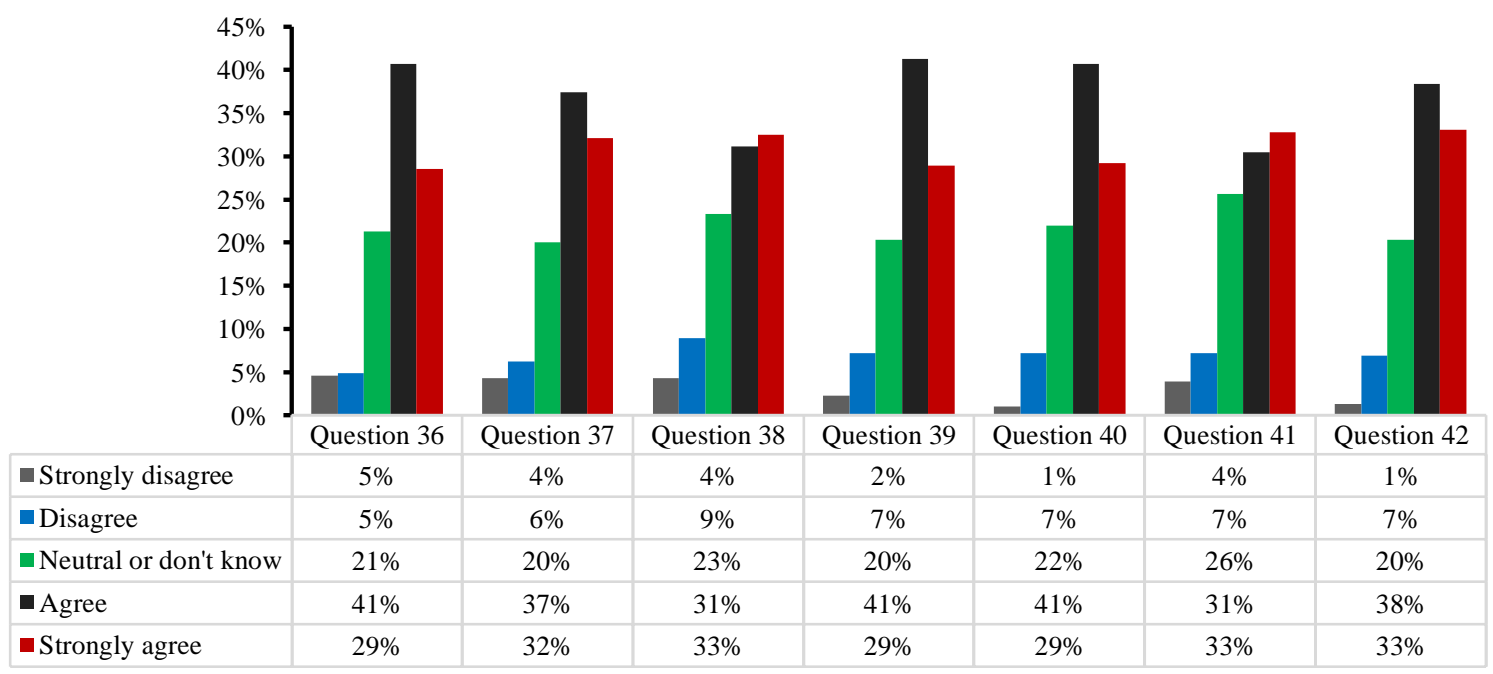

Figure 6. Percentage of student participation in geography-based online learning 


\subsection{Challenges faced by Geography based Online Learning during the Pandemic}

The survey was done among geography students living in rural and urban areas. According to Abidah et al. (2020) \& Rasmitadila et al. (2020), the majority of the students in the rural setting had poor internet connectivity and often experienced blackouts making learning a challenge, especially when signing into the online system. Contrarily, students from urban areas such as Banda Aceh city and Lhoksumawe city did not experience challenges with internet connectivity though they had frequent blackouts. Therefore, the lack of a reliable power supply was a major and common problem. Also, most of the students had difficulties using the online learning model and were not familiar with the social media platforms. This calls for the measure from all stakeholders, including the government, teachers, and students, to adopt technology as a way of mitigating learning challenges faced caused by the pandemic (Leacock \& Warrican, 2020).

Internet connectivity was essential in enhancing the effective implementation of the online learning system. Poor network and lack of a reliable power supply led to a partial participation of students contributing to the drawbacks experienced during online learning (Rejeki \& Mukminan, 2020). Most parts of Aceh Province are categorized as the least developed frontier where internet connectivity is yet to be installed (Ridha \& Kamil, 2021). Due to these challenges, the students are unable to cover the intended content according to the curriculum.However, it is important to teach geography in relation to the physical location of students. This will help them understand the introduction of landscapes, morphology, and spatial associations linked to online learning (Ikhsan et al., 2018).

To ensure effective implementation of online learning, lecturers have tried various applications to support the system, such as Zoom, Google Meet, Jitsi, and Webex. The applications are evaluated with the help of the students in determining the advantages and disadvantages before choosing the most reliable in terms of installation, bundle consumption, learning features, sound quality, pictures, and adaptability. The most accepted application by most students could be chosen as the best fit for geography-based online learning.

\section{Conclusion}

The geography-based online learning during the pandemic in higher education institutions was effective, with a score of $79 \%$. Factors that hindered online learning during the Covid-19 pandemic included poor internet connectivity and lack of power, especially for students from a rural setting. Besides, most students from rural areas come from low household income backgrounds, which could not enable them to buy bundles for the internet 
compared to their counterparts living in the city. This research concluded that learning geography during a pandemic was quite effective. However, there is a need to solve the identified challenges and integrate efforts between the government and various stakeholders in improving the online learning platform. Furthermore, based on the description given, follow-up research can be conducted to determine the impact of developing online-based learning, teaching material, multimedia, and skills in the face of a pandemic.

\section{Conflict of Interest}

The authors declare that there is no conflict of interest with any financial, personal, other people or organizations related to the material in this study.

\section{References}

Abidah, A., Hidaayatullaah, H. N., Simamora, R. M., Fehabutar, D., \& Mutakinati, L. (2020). The impact of covid-19 to Indonesian education and its relation to the philosophy of "Merdeka Belajar." Studies in Philosophy of Science and Education, 1(1), 38-49. https://doi.org/10.46627/sipose.v1i1.9.

Allen, J., Rowan, L., \& Singh, P. (2020). Teaching and teacher education in the time of COVID-19. Asia-Pacific Journal of Teacher Education, 48(3), 233-236. https://doi.org/10.1080/1359866X.2020.1752051.

Baloran, E. T. (2020). Knowledge, attitudes, anxiety, and coping strategies of students during covid-19 pandemic. Journal of Loss and Trauma, 25(8), 635-642. https://doi.org/10.1080/15325024.2020.1769300.

Barnes, R., Hall, R., Lowe, V., Pottinger, C., \& Popham, A. (2020). Lessons from an online teacher preparation program: Flexing work experience to meet student needs and regulators' requirements in the United States. Journal of Education for Teaching, 46(4), 528-535. https://doi.org/10.1080/02607476.2020.1802203.

Bryson, J. R., \& Andres, L. (2020). Covid-19 and rapid adoption and improvisation of online teaching: Curating resources for extensive versus intensive online learning experiences. Journal of Geography in Higher Education, 44(4), 608-623. https://doi.org/10.1080/03098265.2020.1807478.

Coolican, M., Borras, J. C., \& Strong, M. (2020). Argentina and the covid-19: Lessons learned from education and technical colleges in Buenos Aires Province. Journal of Education for Teaching, 46(4), 484-496. https://doi.org/10.1080/02607476.2020.1802204.

Halliwell, J. (2020). Applying social media research methods in geography teaching: benefits and emerging challenges? Journal of Geography, 119(3) 108-113. https://doi.org/10.1080/00221341.2020.1755717. 
Hazen, H. (2020). Teaching covid-19 topics in a geographic framework. The Geography Teacher, 17(2), 33-43. https://doi.org/10.1080/19338341.2020.1764375.

Hazen, H. D., \& Alberts, H. C. (2021). Innovative approaches to teaching in geography. The Geography Teacher, 18(1), 1-2. https://doi.org/10.1080/19338341.2020.1861549.

Holloway, P., Kenna, T., Linehan, D., O’Connor, R., Bradley, H., O’Mahony, B., \& Pinkham, R. (2021). Active learning using a smartphone app: Analysing land use patterns in Cork City, Ireland. Journal of Geography in Higher Education, 45(1), 4762. https://doi.org/10.1080/03098265.2020.1802703.

Ikhsan, F. A., Kurnianto, F. A., Apriyanto, B., \& Nurdin, E. A. (2018). Geography literacy of observation introduction landscape representation place for student experience (ethnomethodology perspective). Geosfera Indonesia, 3(2), 131-145. https://doi.org/10.19184/geosi.v3i2.8384.

Jo, I., \& Bednarz, S. W. (2014). Developing pre-service teachers' pedagogical content knowledge for teaching spatial thinking through geography. Journal of Geography in Higher Education, 38(2), 301-313. https://doi.org/10.1080/03098265.2014.911828.

Leacock, C. J., \& Warrican, S. J. (2020). Helping teachers to respond to covid-19 in the Eastern Caribbean: Issues of readiness, equity and care. Journal of Education for Teaching, 46(4), 575-585. https://doi.org/10.1080/02607476.2020.1803733.

Moorhouse, B. L. (2020). Adaptations to a face-to-face initial teacher education course 'forced' online due to the COVID-19 pandemic. Journal of Education for Teaching, 46(4), 609-611. https://doi.org/10.1080/02607476.2020.1755205.

Morgan, H. (2020). Best practices for implementing remote learning during a pandemic. The Clearing House: A Journal of Educational Strategies, Issues and Ideas, 93(3), 135141. https://doi.org/10.1080/00098655.2020.1751480.

Mutton, T. (2020). Teacher education and Covid-19: Responses and opportunities for new pedagogical initiatives. Journal of Education for Teaching, 46(4), 439-441. https://doi.org/10.1080/02607476.2020.1805189.

Nasri, N. M., Husnin, H., Mahmud, S. N. D., \& Halim, L. (2020). Mitigating the covid-19 pandemic: A snapshot from Malaysia into the coping strategies for pre-service teachers' education. Journal of Education for Teaching, 46(4), 546-553. https://doi.org/10.1080/02607476.2020.1802582.

Osman, M. E. (2020). Global impact of COVID-19 on education systems: The emergency remote teaching at Sultan Qaboos University. Journal of Education for Teaching, 46(4), 463-471. https://doi.org/10.1080/02607476.2020.1802583.

Rasmitadila, Aliyyah, R. R., Rachmadtullah, R., Samsudin, A., Syaodih, E., Nurtanto, M., \& Tambunan, A. R. S. (2020). The Perceptions of Primary School Teachers of Online Learning during the COVID-19 Pandemic Period: A Case Study in Indonesia. Journal of Ethnic and Cultural Studies, 7(2), 90-109. https://doi.org/10.29333/ejecs/388. 
Rejeki, W. Y., \& Mukminan, M. (2020). Development of multimedia learning geography based on adobe flash to increase students' Curiosity. Geosfera Indonesia, 5(3), 318334. https://doi.org/10.19184/geosi.v5i3.14765.

Ridha, S., \& Kamil, P. A. (2021). The problems of teaching geospatial technology in developing countries: concepts, curriculum, and implementation in Indonesia. Journal of Geography, 120(2), 72-82. https://doi.org/10.1080/00221341.2021.1872681.

Salehudin, M., Sarimin, D. S., Steven, R. H., Yunus, M., \& Safiah, I. (2020). Using Instagram to Support Creative Learning and Project Based Learning. International Journal of Advanced Science and Technology, 29(5), 4866-4876.

Sandhu, P., \& de Wolf, M. (2020). The impact of covid-19 on the undergraduate medical curriculum. Medical Education Online, 25(1), 1-2. https://doi.org/10.1080/10872981.2020.1764740.

Satuan Tugas (2020). Satuan Tugas Percepatan Penanganan COVID-19. Retrieved from https://covid19.go.id/.

Scull, J., Phillips, M., Sharma, U., \& Garnier, K. (2020). Innovations in teacher education at the time of COVID19: An Australian perspective. Journal of Education for Teaching, 46(4), 497-506. https://doi.org/10.1080/02607476.2020.1802701.

Setyosari, P. (2013). Metode Penelitian Pendidikan dan Pengembangan (3rd ed.). Jakarta: Kencana Prenada Group.

Suhendro, S., Sugandi, D., \& Ruhimat, M. (2021). Analysis on factors influencing geography teachers' ability in constructing High-Order Thinking Skills (HOTS) Assessment Instrument. Geosfera Indonesia, 6(2), 205-221. https://doi.org/10.19184/geosi.v6i2.21428.

Talidong, K. J. B., \& Toquero, C. M. D. (2020). Philippine teachers' practices to deal with anxiety amid covid-19. Journal of Loss and Trauma, 25(6), 573-579. https://doi.org/10.1080/15325024.2020.1759225.

Thomas, M., \& Bryson, J. R. (2021). Combining proximate with online learning in real-time: Ambidextrous teaching and pathways towards inclusion during COVID-19 restrictions and beyond. Journal of Geography in Higher Education, 45(3), 446-464. https://doi.org/10.1080/03098265.2021.1900085. 